\title{
PERLINDUNGAN HAK-HAK KONSTITUSIONAL PENYANDANG DISABILITAS (RIGHTS OF PERSONS WITH DISABILITIES)
}

\author{
Zulkarnain Ridlwan \\ Dosen Bagian Hukum Tata Negara Fakultas Hukum Universitas Lampung \\ email: zulkarnain.ridlwan@fh.unila.ac.id, zulkarnainridlwan@gmail.com
}

\begin{abstract}
Abstrak
Tujuan penulisan ini yaitu mendeskripsikan urgensitas perlindungan hak-hak penyandang disabilitas sebagai hak konstitusional dan pentingnya pengaturan hal tersebut dalam peraturan di tingkat daerah. Berdasarkan penelitian normatif dan mengamati kenyataan dalam perkembangan sosial disimpulkan bahwa perlindungan terhadap hak-hak penyandang disabilitas (rights of persons with disabilities) merupakan hak konstitusional sebagaimana dimaksud Pasal $28 \mathrm{H}$ ayat (2) UUD 1945, ditegaskan dengan UU ratifikasi konvensi mengenai hak-hak penyandang disabilitas. Perlindungan penyandang disabilitas ditingkat daerah sangatlah penting dituangkan dalam peraturan daerah sebagai sarana keberpihakan pemerintah daerah terhadap penyandang disabilitas, hal ini juga sesuai dengan rumusan UU Nomor 4 Tahun 1997 dan UU Nomor 19 Tahun 2011.
\end{abstract}

Kata Kunci: Perlindungan, Hak Konstitusional, Penyandang Disabilitas, Daerah

\section{Pendahuluan}

Salah satu prinsip yang harus dijalankan dalam suatu negara hukum adalah jaminan terhadap hakhak asasi manusia (HAM). HAM sebagai hak dasar yang secara kodrati melekat pada diri manusia, bersifat universal dan langgeng, semestinya selalu dilindungi, dihormati, dan dipertahankan, terlebih bagi kelompok rentan khususnya penyandang disabilitas. Hal inilah yang mendasari Majelis Umum Perserikatan Bangsa-Bangsa untuk mengeluarkan Resolusi Nomor A/61/106 mengenai Convention on the Rights of Persons with Disabilities (Konvensi tentang HakHak Penyandang Disabilitas) pada 13 Desember 2006. Resolusi ditingkat global tersebut memuat hak-hak penyandang disabilitas dan menyatakan akan diambil langkahlangkah untuk menjamin pelaksanaan konvensi ini.
Memenuhi unsur yang melekat pada negara hukum, Pemerintah Indonesia telah ikut menandatangani Convention on the Rights of Persons with Disabilities (Konvensi mengenai Hak-Hak Penyandang Disabilitas) pada tanggal 30 Maret 2007 di New York. Penandatanganan tersebut menunjukan kesungguhan Negara Indonesia untuk menghormati, melindungi, memenuhi, dan memajukan hak-hak penyandang disabilitas, yang pada akhirnya diharapkan dapat memenuhi kesejahteraan para penyandang disabilitas.

Menindaklanjuti penandatanganan konvensi tersebut, diterbitkanlah Undang-Undang Nomor 19 Tahun 2011 Tentang Pengesahan Convention On The Rights Of Persons With Disabilities (Konvensi Mengenai Hak-Hak Penyandang Disabilitas).

Pada aturan yang lebih tinggi, Undang-Undang Dasar 1945 sebagai 
sumber kebijakan pokok atau sumber politik hukum Indonesia telah mengatur bahwa" "Setiap orang mendapat kemudahan dan perlakuan khusus untuk memperoleh kesempatan dan manfaat yang sama guna mencapai persamaan dan keadilan". Perlakuan khusus bagi pemilik kekhususan sebagai penyandang disabilitas merupakan hak konstitusional, oleh karena itu harus dijalankan dan negara wajib mengupayakan pemenuhannya.

Sebelum adanya UU Nomor 19 Tahun 2011, dalam upaya melindungi, menghormati, memajukan, dan memenuhi hak-hak penyandang disabilitas, Pemerintah Indonesia telah membentuk berbagai peraturan perundang-undangan yang sebagian substansinya mengatur perlindungan terhadap penyandang disabilitas. Berbagai peraturan perundang-undangan tersebut antara lain: ${ }^{2}$

1. Undang-Undang Nomor 4 Tahun 1979 tentang Kesejahteraan Anak;

2. Undang-Undang Nomor 4 Tahun 1997 tentang Penyandang Cacat;

3. Undang-Undang Nomor 39 Tahun 1999 tentang Hak Asasi Manusia;

4. Undang-Undang Nomor 23 Tahun 2002 tentang Perlindungan Anak;

5. Undang-Undang Nomor 28 Tahun 2002 tentang Bangunan Gedung;

\footnotetext{
${ }^{1}$ Pasal 28H UUD NRI 1945

${ }^{2}$ Lihat Penjelasan Umum UU Nomor 19 Tahun 2011 Tentang Pengesahan Convention On The Rights Of Persons With Disabilities (Konvensi Mengenai Hak-Hak Penyandang Disabilitas), Tambahan Lembaran Negara Republik Indonesia Nomor 5251.
}

6. Undang-Undang Nomor 13 Tahun 2003 tentang Ketenagakerjaan;

7. Undang-Undang Nomor 20 Tahun 2003 tentang Sistem Pendidikan Nasional;

8. Undang-Undang Nomor 3 Tahun 2005 tentang Sistem Keolahragaan Nasional;

9. Undang-Undang Nomor 23 Tahun 2007 tentang Perkeretaapian;

10. Undang-Undang Nomor 17 Tahun 2008 tentang Pelayaran;

11. Undang-Undang Nomor 1 Tahun 2009 tentang Penerbangan;

12. Undang-Undang Nomor 11 Tahun 2009 tentang Kesejahteraan Sosial;

13. Undang-Undang Nomor 22 Tahun 2009 tentang Lalu Lintas dan Angkutan Jalan;

14. Undang-Undang Nomor 25 Tahun 2009 tentang Pelayanan Publik;

15. Undang-Undang Nomor 36 Tahun 2009 tentang Kesehatan; dan

16. Undang-Undang Nomor 13 Tahun 2011 tentang Penanganan Fakir Miskin.

Keberadaan sejumlah undangundang tersebut merupakan perwujudan upaya perlindungan, penghormatan, pemajuan, dan pemenuhan hak-hak penyandang disabilitas, sekaligus menjadi dasar hukum yang sangat jelas mengenai pentingnya pengaturan perlindungan hak penyandang disabilitas diseluruh segi kehidupan masyarakat.

Ketidaksamaan pemahaman bersama akan keberadaan para penyandang disabilitas disekitar kita merupakan faktor lain yang menjadikan pengaturan tentang perlindungan mereka menjadi 
penting. Pola pikir dan pandangan masyarakat terhadap penyandang disabilitas lebih identik dengan orang yang dianggap tidak produktif, tidak mampu menjalankan tugas, sehingga harus diberi perlakuan laiknya orang yang tidak cakap. Padahal yang dibutuhkan para penyandang disabilitas bukanlah sekedar rasa kasihan atas ketidakmampuan sehingga melahirkan stigma negatif terhadap mereka, melainkan kesetaraan hak sehingga dapat sama dengan masyarakat Indonesia lainnya.

Ditingkat nasional, tuntutan akan hak dan diadakannya sarana dan prasarana aksesibilitas fisik maupun non-fisik bagi penyandang disabilitas telah sering disuarakan oleh para aktivis Organisasi Penyandang Disabilitas (Disabled People Organisation). Sebagian hak sudah diupayakan dan direalisasikan oleh pemerintah, seperti: pembangunan sekolah luar biasa, dibangunnya fasilitas-fasilitas di beberapa gedung, penerjemah berita penyandang disabilitas rungu/tuli di televisi (sekarang justru ditiadakan), transportasi khusus disabilitas dan sebagainya, walaupun masih minim dan kadang tidak terurus.

Meski Indonesia memiliki undang-undang yang mengatur tentang penyandang disabilitas, kenyataan di lapangan, implementasi penerapan sanksi hukum sangat lemah. Dibidang ketenagakerjaan, memperkerjakan penyandang disabilitas pada perusahaan dipandang sebelah mata. Kesempatan memperoleh pendidikan inklusif terbatas. Pelayanan rehabilitasi dan sosial masyarakat yang tidak merata, dan lainnya. Potret keadaan pada tataran pemerintahan daerah pun tidak berbeda.

Oleh karena itu, jika ditingkat pusat telah diratifikasi konvensi penyandang disabilitas kedalam undang-undang, maka menghadirkannya dalam bentuk peraturan daerah yang disesuaikan dengan kekhasan dan kemampuan daerah menjadi hal penting. Adanya hambatan keterbatasan dari para penyandang disabilitas harus dapat diatasi oleh pemerintah daerah dengan mengakomodasi prinsip kesetaraan, nondiskriminasi, HAM, dan kesempatan yang sama. Berdasarkan hal tersebut, permasalahan yang diangkat dalam tulisan ini adalah pemajuan hak-hak penyandang disabilitas dalam konsep perlindungan hak asasi manusia (HAM) juga sebagai hak konstitusional, serta upaya apa yang dapat dilakukan pemerintah daerah untuk ikut melindungi dan memajukan hak-hak penyandang disabilitas.

\section{Pembahasan}

\subsection{Urgensi Perlindungan Hak Penyandang Disabilitas sebagai Bentuk Perlindungan Hak Konstitusonal}

Setiap negara hukum, termasuk negara hukum Indonesia, hukum ditempatkan sebagai aturan main dalam penyelenggaraan kenegaraan, pemerintah, dan kemasyarakatan, sementara tujuan hukum itu sendiri antara lain untuk menata masyarakat yang damai, adil dan bermakna. Artinya sasaran dari negara hukum adalah terciptanya kegiatan kenegaraan pemerintahan dan kemasyarakatan yang bertumpu pada keadilan, kedamaian dan kemanfaatan atau kebermaknaan. 
Setiap negara hukum, eksistensi hukum dijadikan sebagai instrumen dalam menata kehidupan kenegaraan, pemerintahan dan kemasyarakatan. Salah satu unsur yang melekat pada konsep negara hukum adalah perlindungan HAM sebagai hak konstitusional.

Tujuan pembangunan nasional adalah mewujudkan masyarakat adil dan makmur yang merata material dan spiritual berdasarkan Pancasila dan Undang-Undang Dasar 1945 dalam wadah Negara Kesatuan Republik Indonesia yang merdeka, berdaulat, bersatu, dan berkedaulatan rakyat dalam suasana perikehidupan bangsa yang aman, tenteram, tertib, dan dinamis dalam lingkungan pergaulan dunia yang merdeka, bersahabat, tertib, dan damai. Pembangunan nasional sebagai pengamalan Pancasila yang mencakup seluruh aspek kehidupan bangsa diselenggarakan bersama oleh masyarakat dan Pemerintah.

Masyarakat adalah pelaku utama pembangunan dan Pemerintah berkewajiban mengarahkan, membimbing, melindungi serta menumbuhkan suasana yang menunjang. Kegiatan masyarakat dan kegiatan Pemerintah saling menunjang, saling mengisi, dan saling melengkapi dalam satu kesatuan langkah menuju tercapainya tujuan pembangunan nasional.

\begin{tabular}{lcr}
\multicolumn{1}{c}{ Sebagai } & warga & negara \\
Indonesia, & kedudukan, & hak, \\
kewajiban, & dan peran & serta
\end{tabular} penyandang disabilitas adalah sama dengan warga negara lainnya. Bahkan UUD 1945 telah mengatur bahwa "Setiap orang mendapat kemudahan dan perlakuan khusus untuk memperoleh kesempatan dan manfaat yang sama guna mencapai persamaan dan keadilan".
Perlakuan khusus bagi pemilik kekhususan sebagai penyandang disabilitas merupakan hak konstitusional, karenanya harus dijalankan dan negara wajib mengupayakan pemenuhannya. Oleh karena itu, peningkatan peran para penyandang disabilitas dalam pembangunan nasional sangat penting untuk mendapat perhatian dan didayagunakan sebagaimana mestinya.

Hingga saat ini sarana dan upaya untuk memberikan perlindungan hukum terhadap kedudukan, hak, kewajiban, dan peran penyandang disabilitas telah dilakukan melalui berbagai peraturan perundang-undangan, yaitu yang mengatur masalah ketenagakerjaan, pendidikan nasional, kesehatan, kesejahteraan sosial, lalu lintas dan angkutan jalan, perkeretaapian, pelayaran, penerbangan, dan kepabeanan. Namun dalam lingkup pemerintahan di daerah belum banyak tersedia peraturan daerah yang dapat memberikan perlindungan yang dimaksud. Suatu perlindungan yang mencakup seluruh hak yang dapat diakses oleh masyarakat secara umum, yang sering disebut aksesibilitas. Pentingnya aksesibilitas kepada lingkungan fisik, sosial, ekonomi dan kebudayaan, kesehatan dan pendidikan, serta informasi dan komunikasi, yang memungkinkan penyandang disabilitas untuk menikmati sepenuhnya semua hak asasi manusia dan kebebasan fundamental.

Dari aspek sosiologis, perlindungan terhadap penyandang disabilitas sejalan dengan prinsip keadilan sosial yang merupakan nilai dasar bernegara di Indonesia. Bahkan upaya perlindungan saja belumlah 
memadai; dengan pertimbangan bahwa jumlah penyandang disabilitas akan meningkat pada masa yang akan datang, masih diperlukan lagi sarana dan upaya lain terutama dengan penyediaan sarana untuk memperoleh kesamaan kesempatan bagi penyandang disabilitas dalam segala aspek kehidupan dan penghidupan, khususnya dalam memperoleh pendidikan dan pekerjaan dalam rangka mewujudkan kesejahteraan sosial.

Kesejahteraan sosial yang dimaksud adalah suatu tata kehidupan dan penghidupan sosial material maupun spiritual yang diliputi oleh rasa keselamatan, kesusilaan, dan ketenteraman lahir batin yang memungkinkan bagi setiap warga negara untuk mengadakan usaha pemenuhan kebutuhan-kebutuhan jasmaniah, rohaniah, dan sosial yang sebaikbaiknya bagi diri, keluarga, serta masyarakat dengan menjunjung tinggi hak dan kewajiban warga negara sesuai dengan Pancasila. Oleh karena itu, sesuai dengan ketentuan mengenai kedudukan, hak, dan kewajiban warga negara sebagaimana dimaksud dalam Undang-Undang Dasar 1945, perlu dilakukan upaya-upaya yang lebih memadai, terpadu, dan berkesinambungan guna mewujudkan kemandirian dan kesejahteraan penyandang disabilitas, termasuk pada lingkup daerah provinsi, dan kabupaten/kota

Kesempatan untuk mendapatkan kesamaan kedudukan, hak, dan kewajiban bagi penyandang disabilitas hanya dapat diwujudkan jika tersedia aksebilitas, yaitu suatu kemudahan bagi penyandang disabilitas untuk mencapai kesamaan kesempatan dalam memperoleh kesamaan kedudukan, hak, dan kewajiban sehingga perlu diadakan upaya penyediaan aksebilitas bagi penyandang cacat. Dengan upaya dimaksud, diharapkan penyandang disabilitas dapat berintegrasi secara total dalam mewujudkan tujuan pembangunan nasional pada umumnya serta meningkatkan kesejahteraan sosial penyandang disabilitas pada khususnya. Karena itu, peraturan daerah tentang penyelenggaraan perlindungan penyandang disabilitas ini merupakan jawaban atas kebutuhan hukum masyarakat khususnya para penyandang disabilitas di tingkat provinsi atau kabupaten/kota.

$$
\text { Penyelenggaraan upaya }
$$

peningkatan kesejahteraan sosial yang antara lain dilaksanakan melalui kesamaan kesempatan bagi penyandang disabilitas pada hakikatnya menjadi tanggung jawab bersama Pemerintah, masyarakat, keluarga, dan penyandang disabilitas sendiri. Oleh karena itu diharapkan semua unsur tersebut berperan aktif untuk mewujudkannya. Dengan kesamaan kesempatan tersebut diharapkan para penyandang disabilitas dapat melaksanakan fungsi sosialnya dalam arti mampu berintegrasi melalui komunikasi dan interaksi secara wajar dalam hidup bermasyarakat.

$$
\text { Kesamaan kesempatan }
$$
dilaksanakan melalui penyediaan aksebilitas baik oleh Pemerintah maupun masyarakat, yang dalam pelaksanaannya disertai dengan upaya peningkatan kesadaran dan tanggung jawab masyarakat terhadap keberadaan penyandang cacat, yang merupakan unsur penting dalam rangka pemberdayaan penyandang disabilitas. 
Secara yuridis, peraturan daerah tentang penyelenggaraan perlindungan penyandang cacat sejalan dengan Undang-Undang Nomor 4 Tahun 1997 tentang Penyandang Cacat dan UndangUndang Nomor 19 Tahun 2011 tentang Pengesahan Convention On The Rights of Persons With Disabilities (Konvensi Mengenai Hak-Hak Penyandang Disabilitas). Pada hakekatnya undang-undang pertama dan hasil ratifikasi ini memberikan rumusan hak-hak para penyandang disabilitas sebagaimana tertera dalam Konvensi Mengenai Hak-hak Penyandang Disabilitas yang disahkan oleh Sidang Umum PBB tahun 2006.

Dengan ratifikasi itu, pemerintah harus menjamin hak-hak penyandang disabilitas yang diatur dalam konvensi yakni hak bebas dari penyiksaan atau perlakuan yang kejam, tidak manusiawi, merendahkan martabat, bebas dari eksploitasi, kekerasan dan perlakuan semena-mena. Hak penyandang disabilitas lain yakni mendapatkan penghormatan atas integritas mental dan fisik berdasarkan kesamaan dengan orang lain. Termasuk di dalamnya hak untuk mendapat perlindungan dan pelayanan sosial dalam rangka kemandirian.

Berkaca pada perkembangan perlindungan dan pemajuan hak asasi manusia di tingkat global dan di Indonesia, maka keberadaan peraturan mengenai hal ini di tingkat daerah akan berdampak positif guna memberikan jaminan kepastian hukum bagi penghormatan, perlindungan, pemenuhan dan pemajuan hak-hak penyandang disabilitas di segala bidang. Merujuk pada istilah-istilah yang digunakan pada Undang-Undang Nomor 19
Tahun 2011, maka istilah "cacat' lebih tepat diganti dengan istilah 'disabilitas'. Dikarenakan peraturan daerah ini banyak menekankan pada penyediaan sarana dan prasarana dalam rangka mendukung implementasinya, maka penting untuk ada kesiapan pemerintah daerah dan pemangku kepentingannya lainnya untuk menyiapkan pra kondisi.

\subsection{Perlindungan Penyandang Disabilitas di Tingkat Daerah}

Konsep negara hukum yang demokratis menggariskan bahwa keberadaan peraturan perundangundangan, termasuk peraturan daerah, dimaksudkan untuk mewujudkan prinsip-prinsip dasar negara hukum itu sendiri. Peraturan perundang-undangan juga akan memberikan garis batas hak dan kewajiban yang tegas antara pemerintah dengan masyarakat. Dengan demikian, hak masyarakat dijamin dan dilindungi dengan peraturan perundang-undangan.

Dalam konteks hubungan antara pemerintah pusat dan pemerintah daerah, produk dari keseluruhan peraturan daerah merupakan manifestasi otonomi daerah yang akan menentukan berhasil tidaknya desentralisasi yang telah diberikan secara atributif oleh undang-undang. Cheema, Shabbir G., dan Rondinelli ${ }^{3}$ menyarankan beberapa kriteria untuk menguji kebijakan desentralisasi (peraturan ditingkat daerah) diantaranya yaitu meningkatkan "responsifitas" pemerintah terhadap kebutuhan dan

\footnotetext{
${ }^{3}$ Cheema, Shabbir G, dan Rondinelli. 1984. Decentralizaytion and Development, Policy Implementation in Developing Countries. California: Sage Publications.
} 
tuntutan berbagai kelompok dalam masyarakat.

Berkenaan dengan hal tersebut, peraturan daerah dibuat atas dasar tujuan-tujuan tertentu yang ingin dicapai yang dilandaskan pada pedoman atau standar norma yang digariskan oleh pemerintah. Peraturan daerah sebagai instrumen penyelenggaraan kekuasaan pemerintah daerah harus mempunyai karakter yang menghormati, melindungi dan memenuhi hak-hak masyarakat, khususnya masyarakat penyandang disabilitas dalam pelayanan publik yang diselenggarakannya. Hal ini sebagai bentuk responsifitas pemerintah terhadap kebutuhan penyandang disabilitas sebagai bagian dari kelompok masyarakat.

Perlindungan menurut Kamus Besar Bahasa Indonesia adalah 1) tempat berlindung atau 2) hal (perbuatan, dsb) memperlindungi. ${ }^{4}$ Penyandang disabilitas, yaitu orang yang memiliki keterbatasan fisik, mental, intelektual, atau sensorik dalam jangka waktu lama yang dalam berinteraksi dengan lingkungan dan sikap masyarakatnya dapat menemui hambatan yang menyulitkan untuk berpartisipasi penuh dan efektif berdasarkan kesamaan hak.

Meski dalam Kamus Besar Bahasa Indonesia, kata "disabilitas" belum tercantum namun mengacu pada Undang-Undang Nomor 19 Tahun 2011 istilah yang digunakan untuk menyebut penyandang ketidakmampuan yaitu disabilitas. Disabilitas merupakan kata serapan

4 Tim Penyusun Kamus Pusat Pembinaan dan Pengembangan Bahasa, Kamus Besar Bahasa Indonesia, (Jakarta: Balai Pustaka, 1988), hlm 526. dari bahasa Inggris "disability” yang berarti ketidakmampuan. Meski memiliki arti yang sama, namun perspektif yang melekat pada kata "cacat" dan kata "disabilitas" berbeda. Penyandang cacat seakan subyek hukum yang dipandang kurang diberdayakan. Istilah "penyandang cacat" akan memberikan predikat kepada seseorang dengan tanda atau label negatif yaitu cacat pada keseluruhan pribadinya. Kata "cacat" berkonotasi sesuatu yang negatif, tidak sempurna atau rusak. Selain itu kata "cacat" juga digunakan pada kondisi keadaan barang atau produk yang tidak sempurna.

Penyandang disabilitas dapat diartikan individu yang mempunyai keterbatasan fisik atau mental/intelektual. Oleh karena itu penggunaan istilah "penyandang cacat" dalam Undang-Undang Nomor 4 Tahun 1997 pun perlu direvisi sesuai dengan UndangUndang Nomor 19 Tahun 2011. Seterusnya untuk peraturan perundang-undangan dibawahnya juga menggunakan istilah tersebut, termasuk peraturan daerah.

Perlindungan penyandang disabilitas merupakan istilah yang dipakai untuk menggambarkan perlindungan hukum yang diberikan kepada penyandang disabilitas dalam usahanya untuk memenuhi kebutuhannya dari hal-hal yang dapat merugikan penyandang disabilitas itu sendiri. Pada akhirnya, perlindungan ini juga dapat diartikan sebagai pengakuan bahwa diskriminasi berdasarkan disabilitas merupakan pelanggaran terhadap martabat dan nilai yang melekat pada setiap orang. Disamping itu, perlindungan penyandang disabilitas juga dapat diartikan sebagai upaya 
menciptakan lingkungan dan fasilitas umum yang aksesibel demi kesamaan kesempatan bagi penyandang disabilitas untuk hidup mandiri dan bermasyarakat.

Dalam hal fasilitas umum misalnya, akan dapat menimbulkan frustrasi bagi para penyandang disabilitas dalam menghadapi kenyataan bahwa berbagai hambatan arsitektural di dalam bangunanbangunan dan fasilitas-fasilitas yang disediakan bagi kepentingan umum ternyata tidak selalu mudah atau bahkan sering tidak memungkinkan bagi mereka untuk berpartisipasi penuh dalam situasi normal, baik dalam bidang pendidikan, pekerjaan maupun rekreasi. Beberapa contoh hambatan arsitektural adalah tidak adanya trotoar, permukaan jalan yang tidak rata, tepian jalan yang tinggi, lubang pintu yang terlalu sempit, lantai yang terlalu licin, tidak tersedianya tempat parkir yang sesuai, tidak tersedia lift, fasilitas sanitasi yang terlalu sempit, telepon umum yang terlalu tinggi, tangga yang tidak berpagar pengaman, jendela atau papan reklame yang menghalangi jalan, dan kondisi arsitektural lainnya. 5

Hal-hal tersebut di atas menjadi masalah bagi penyandang cacat dari jenis dan derajat kecacatan tertentu sehingga mereka tidak dapat merealisasikan kesamaan haknya sebagai warga masyarakat. Sesungguhnya para penyandang cacat tidak mengharapkan dan tidak

5 Didi Tarsidi. Aksisibilitas Lingkungan Fisik Bagi Penyandang Cacat. Makalah disajikan pada Focus Discussion Group tentang Draft Raperda Pelindungan Penyandang Cacat Kota Bandung. Kerjasama antara Lembaga Pengabdian kepada Masyarakat UNPAD dengan Sekretariat DPRD Kota Bandung, 22 Nopember 2008. Hlm. 2. pula memerlukan lebih banyak hak daripada orang-orang pada umumnya. Mereka hanya menghendaki agar dapat bergerak di dalam lingkungannya dengan tingkat kenyamanan, kemudahan dan keselamatan yang sama dengan warga masyarakat lainnya, memperoleh kesempatan yang sama untuk berpartisipasi dalam kehidupan yang normal, dapat semandiri mungkin dalam batas-batas kemampuannya. Tersedianya bangunan dan fasilitas yang dapat diakses oleh semua orang merupakan persoalan kesamaan kesempatan dan keadilan sosial. Akses terhadap fasilitas-fasilitas umum merupakan hak, bukan pilihan semata. Lebih dari itu, penataan lingkungan yang sesuai dengan kaidah aksesibilitas akan juga memberikan lebih banyak kenyamanan bagi warga masyarakat pada umumnya.

Menurut Pusat Data dan Informasi Kesejahteraan (2008) jumlah penyandang disabilitas di Indonesia mencapai 1.544.184 orang. ${ }^{6}$ Dari jumlah tersebut, terdapat kecenderungan meningkatnya jumlah penyandang disabilitas dari tahun ke tahun. Data tersebut dalam prosentase berarti mencapai 3,11 \% dari jumlah penduduk Indonesia. Dari segi prosentase, jumlah ini nampaknya kecil, akan tetapi secara absolut angka 3,11 \% ini akan mencapai sekitar 5,5 juta penduduk Indonesia yang menyandang cacat.

Data diatas menunjukkan bahwa hadirnya peraturan ditingkat daerah yang mengatur perlindungan

\footnotetext{
${ }^{6}$ Rencana Strategis 2010-2014 Kementerian Sosial, hlm. 3. Sebagaimana dapat diakses pada laman http://www.depsos.go.id/users/nawir/File/Isi \%20Renstra\%202010-2014.pdf
} 
terhadap penyandang disabilitas merupakan hal yang sangat dibutuhkan. Namun sejak diundangkannya Undang-Undang Nomor 4 Tahun 1997 tentang Penyandang Cacat pada Februari 1997 hingga saat ini belum semua daerah memiliki peraturan daerah yang mengatur tentang perlindungan penyandang cacat atau sejenisnya. Meski telah ada Peraturan Pemerintah Nomor 43 Tahun 1998 tentang Upaya Peningkatan Kesejahteraan Sosial Penyandang Cacat namun belum juga ada pengadopsian rumusan yang mengatur hal itu dalam Peraturan daerah.

Pasca ratifikasi Konvensi Mengenai Hak-Hak Penyandang Disabilitas kedalam Undang-Undang Nomor 19 Tahun 2011 tentang Pengesahan Convention On The Rights Of Persons With Disabilities (Konvensi Mengenai Hak-Hak Penyandang Disabilitas) maka menjadi dasar hukum untuk diterbitkannya Peraturan daerah tentang Perlindungan Penyandang Disabilitas. Namun demikian, pembuatan Peraturan daerah ini akan sedikit terkendala dikarenakan belum adanya peraturan pemerintah yang menjadi peraturan pelaksana dari Undang-Undang Nomor 19 Tahun 2011 tersebut.

Meskipun ada Peraturan Pemerintah Nomor 43 Tahun 1998 tentang Upaya Peningkatan Kesejahteraan Sosial Penyandang Cacat, namun dikarenakan telah ada rumusan undang-undang pelengkap, maka substansinya pun memerlukan penyesuaian. Disamping itu, ditingkat nasional juga telah berkembang wacana yang mengarah pada revisi Undang-Undang Nomor 4 Tahun 1997 untuk diselaraskan dengan Undang-Undang Nomor 19 Tahun 2011.

Akan tetapi hal ini tidak menjadi alasan mutlak untuk diundurkannya penerbitan Peraturan daerah, sebab arah rumusan produk hukum yang bersandar baik pada Undang-Undang Nomor 4 Tahun 1997 maupun Undang-Undang Nomor 19 Tahun 2011 telah saling melengkapi. Keberpihakan pemerintah daerah terhadap penyandang disabilitas justru dapat terlihat dalam konteks ini. Berdasar pada arahan pokok yang terdapat didalam kedua undang-undang diatas sebagai payung hukum utama dari peraturan daerah ini, dapat dirumuskan substansi peraturan daerah tentang perlindungan penyandang disabilitas sebagai berikut:

1. Orientasi pengaturan hukum perlindungan penyandang disabilitas dilakukan dengan maksud dan tujuan:

a. untuk memajukan, melindungi, dan menjamin kesamaan hak dan kebebasan yang mendasar bagi semua penyandang disabilitas, serta penghormatan terhadap martabat penyandang disabilitas sebagai bagian yang tidak terpisahkan (inherent dignity).

b. untuk mendapatkan penghormatan atas integritas mental dan fisiknya berdasarkan kesamaan dengan orang lain. Termasuk didalamnya hak untuk mendapatkan perlindungan dan pelayanan sosial dalam rangka kemandirian.

c. untuk meningkatkan kesadaran seluruh masyarakat mengenai penyandang 
disabilitas, dan untuk memelihara penghormatan atas hak-hak dan martabat para penyandang disabilitas.

d. untuk melawan stereotip, prasangka, dan praktikpraktik yang merugikan menyangkut penyandang disabilitas dalam seluruh bagian kehidupan.

e. untuk menumbuhkan penerimaan atas hak-hak penyandang disabilitas.

f. untuk meningkatkan persepsi positif dan kesadaran sosial yang lebih besar terhadap para penyandang disabilitas.

g. untuk memajukan pengakuan terhadap keahlian, kualitas dan kemampuan penyandang disabilitas, serta kontribusi mereka pada tempat kerja dan pasar tenaga kerja.

h. untuk menjamin akses bagi penyandang disabilitas, atas dasar kesetaraan dengan yang lainnya, terhadap lingkungan fisik, transportasi, informasi, dan komunikasi, termasuk teknologi dan sistem informasi dan komunikasi, serta terhadap fasilitas dan layanan lainnya yang terbuka atau tersedia untuk publik, termasuk penghapusan kendala serta halangan terhadap aksesibilitas terhadap bangunan gedung, jalan, sarana transportasi, dan fasilitas dalam dan luar ruang lainnya, termasuk sekolah, perumahan, fasilitas medis, dan tempat kerja.

i. untuk memajukan pemulihan fisik, kognitif dan psikologis, rehabilitasi dan reintegrasi sosial penyandang disabilitas. j. untuk menjamin bahwa penyandang disabilitas tidak dikecualikan dari sistem pendidikan umum berdasarkan alasan disabilitas.

k. untuk menyediakan bagi penyandang disabilitas, program, dan perawatan kesehatan dengan kualitas dan standar yang sama dengan yang disediakan bagi yang lainnya.

1. untuk melarang diskriminasi atas dasar disabilitas terhadap segala bentuk pekerjaan, mencakup kondisi perekrutan, penerimaan dan pemberian kerja, perpanjangan masa kerja, pengembangan karir dan kondisi kerja yang aman dan sehat.

2. Substansi minimal yang hendaknya diatur dalam peraturan daerah ini mencakup:

a. Asas, dan Tujuan penyelenggaraan perlindungan penyandang disabilitas berasaskan keimanan dan ketaqwaan terhadap Tuhan Yang Maha Esa, manfaat, kekeluargaan, adil dan merata, keseimbangan, keserasian dan keselarasan dalam perikehidupan, hukum, kemandirian, ilmu pengetahuan dan teknologi;

b. Tugas dan wewenang pemerintah daerah yaitu menetapkan kebijakan; menetapkan kriteria, standar, prosedur, dan persyaratan, memberikan penghargaan, mengembangkan dan memperkuat kerjasama dengan berbagai pihak, 
melakukan kampanye dan sosialisasi dalam rangka penyelenggaraan

perlindungan penyandang disabilitas;

c. Hak dan kewajiban yang dimiliki penyandang disabilitas dalam segala aspek kehidupan;

d. Kesamaan kesempatan bagi setiap penyandang disabilitas dalam segala aspek kehidupan dan penghidupan serta pengakuan dan penghormatan orang lain terhadap hal itu. Kesamaan kesempatan mencakup bidang Pendidikan, Kesempatan Kerja, Kehidupan Sosial, dan Pelayanan Kesehatan;

e. Aksesibilitas yang mengatur tentang ketersediaan aksesibilitas bagi penyandang disabilitas dalam pemanfaatan dan penggunaan sarana dan prasarana umum serta lingkungan dan sarana angkutan umum;

f. Rehabilitasi mengatur tentang pemungsian kembali dan pengembangan kemampuan baik fisik, mental, dan sosial penyandang disabilitas yang mencakup rehabilitasi medik, rehabilitasi pendidikan, rehabilitasi pelatihan, dan rehabilitasi sosial;

g. Bantuan sosial penyandang disabilitas yang diarahkan untuk memenuhi kebutuhan hidup dasar, pengembangan usaha dalam rangka kemandirian, dan kemudahan dalam memperoleh kesempatan berusaha bagi penyandang disabilitas; h. Pemeliharaan Taraf Kesejahteraan Sosial dengan pemberian perlindungan dan pelayanan agar penyandang disabilitas dapat memperoleh taraf hidup yang wajar;

i. Informasi yang bermanfaat dan berguna untuk kepentingan dalam segala aspek kehidupan dan penghidupan. Termasuk kewajiban bagi penyandang disabilitas yang berjalan kaki atau bersepeda untuk menggunakan tanda khusus;

j. Peran masyarakat dalam rangka berpartisipasi dalam mendayagunakan kemampuan guna mewujudkan kemandirian dan kesejahteraan bagi penyandang disabilitas. Tata cara berpartisipasi diatur lebih lanjut dalam Peraturan Gubernur;

k. Pemberian insentif kepada badan usaha yang telah melakukan upaya perlindungan terhadap penyandang disabilitas dan pemberian penghargaan kepada pihak-pihak yang telah berjasa dalam terlaksananya perlindungan penyandang disabiltas;

l. Pemberdayaan penyandang disabilitas diantaranya dengan pemberian kursus, dan pelatihan. Kemitraan antara pemerintah daerah dengan masyarakat, badan hukum, dan atau badan usaha dalam penyelenggaraan perlindungan penyandang disabilitas dengan prinsipprinsip tertentu;

m. Pembinaan dan pengawasan Pemerintah Provinsi kepada 
Pemerintah Kabupaten/ Kota dengan pemberian pedoman dan arahan, bantuan finansial, bantuan teknis dan supervisi;

n. Kewenangan Pemerintah Provinsi dan Pemerintah Kabupaten/ Kota serta bentuk-bentuk dan mekanisme pemberian sanksi atas pelanggaran peraturan daerah ini;

o. Petugas dan tugas-tugas penyidik dalam rangka penegakan peraturan daerah ini;

p. Ketentuan pidana yang disesuaikan dengan UndangUndang Nomor 4 Tahun 1997 tentang Penyandang Cacat; dan

q. Ketentuan Peralihan mengenai batas akhir waktu penyediaan sarana dan prasarana umum serta lingkungan dan angkutan umum bagi aksesibilitas penyandang disabilitas;

\section{Penutup}

\subsection{Simpulan}

1. Perlindungan terhadap hak-hak penyandang disabilitas (rights of persons with disabilities) merupakan hak konstitusional sebagaimana dimaksud Pasal $28 \mathrm{H}$ ayat (2) UUD 1945, yang juga ditegaskan dengan ratifikasi konvensi mengenai hak-hak penyandang disabilitas.

2. Perlindungan penyandang disabilitas ditingkat daerah sangatlah penting dituangkan dalam peraturan daerah agar dapat memberi kepastian hukum, hal ini disamping sejalan dengan UUD 1945 juga sesuai dengan rumusan Undang-
Undang Nomor 4 Tahun 1997 dan Undang-Undang Nomor 19

Tahun 2011.

\subsection{Saran}

1. Pasca diterbitkannya undangundang ratifikasi konvensi penyandang disabilitas, maka perlu adanya penyeragaman penggunaan istilah "penyandang disabilitas". Oleh karena itu, Pengaturannya ditingkat daerah dapat diberi judul "Perlindungan Penyandang Disabilitas".

2. Meski semangat perlindungan hingga pemenuhan dan pemajuan hak-hak penyandang disabilitas ditingkat daerah sangat penting, namun tidak boleh dilupakan bahwa implikasi dari diadakannya peraturan daerah mengenai hal tersebut ditingkat daerah juga tidaklah sederhana karena ada beban keuangan yang harus ditanggung pemerintah daerah.

\section{Daftar Pustaka}

Cheema, Shabbir G, dan Rondinelli. 1984. Decentralizaytion and Development, Policy Implementation in Developing Countries. California: Sage Publications.

Davenport, F.C.B. 1994. Physical Accessibility: A Step by Step Guide to Eliminate Architectural Barriers. Victoria: Access and Mobility Sub-Committee.

Goldsmith, S. 1976. Designing for The Disabled. London: Royal Institute of Architects Publications Ltd.

Manan, Bagir. 2004. Menyongsong Fajar Otonomi Daerah. Yogyakarta: Pusat Studi 
Hukum Fakultas Hukum

Universitas Islam Indonesia.

Marzuki, Peter Mahmud. 2005.

Penelitian Hukum. Jakarta:

Prenada Media.

Soimin. 2010. Pembentukan Perundang-undangan Negara di Indonesia. Yogyakarta: UII Press.

Tarsidi, Didi. Aksisibilitas Lingkungan Fisik Bagi Penyandang Cacat. Makalah disajikan pada Focus Discussion Group tentang Draft Raperda Pelindungan Penyandang Cacat Kota Bandung. Kerjasama antara Lembaga Pengabdian kepada Masyarakat UNPAD dengan Sekretariat DPRD Kota Bandung, 22 Nopember 2008.

Tim Penyusun Kamus Pusat Pembinaan dan Pengembangan Bahasa. 1988. Kamus Besar Bahasa Indonesia. Jakarta: Balai Pustaka. 